\title{
FAKTOR-FAKTOR YANG MEMENGARUHI SIKAP \\ TERHADAP LARANGAN MEROKOK PADA MAHASISWA
}

\author{
Ryan Christian Prasetya dan Margaretha Sih Setija Utami
}

Fakultas Psikologi Universitas Katolik Soegijapranata

cicih@unika.ac.id

\begin{abstract}
ABSTRAKSI
Konsumsi tembakau atau rokok memiliki dampak negatif bagi kesehatan baik bagi yang mengonsumsi secara langsung (perokok aktif) maupun secara tidak langsung (perokok pasif). Berbagai gerakan yang mendukung mengenai pengurangan rokok telah dilakukan oleh berbagai lembaga di dunia, salah satunya Fakultas Psikologi Universitas Katolik Soegijapranata. Penelitian ini merupakan studi deskriptif dengan tujuan memberikan gambaran mengenai faktor-faktor yang memengaruhi sikap mahasiswa terhadap larangan merokok. Penelitian ini menggunakan 100 orang sampel yang tersebar dari tahun angkatan 2012 hingga 2015. Analisis data yang digunakan adalah metode statistik nonparametrik terhadap delapan variabel penelitian. Hasil penelitian menunjukkan bahwa faktor-faktor yang signifikan memengaruhi sikap mahasiswa terhadap larangan merokok adalah behavioral belief, jenis kelamin, orang lain yang dianggap penting, status merokok dan niat untuk berhenti merokok. Sedangkan, kebudayaan dan media massa tidak memengaruhi secara signifikan.
\end{abstract}

Kata Kunci: larangan merokok, sikap, mahasiswa.

\section{LATAR BELAKANG}

Konsumsi tembakau atau

rokok memiliki dampak negatif

bagi kesehatan baik bagi yang

mengonsumsi secara langsung

(perokok aktif) maupun secara

tidak langsung (perokok pasif).

Setiap batang rokok yang dikonsumsi mengandung 4.800 zat kimia berbahaya, antara lain nikotin, tar, karbon monoksida (CO), karbon dioksida $\left(\mathrm{CO}_{2}\right)$, amoniak, kadmium, hidrogen sianida, oksida nitrogen, fenol, benzopiren dan senyawa 
hidrokarbon (Yahya, 2010, hal. 45-46).

Riset yang dilakukan WHO memperkirakan sebanyak enam juta orang meninggal setiap tahunnya diakibatkan oleh penggunaan tembakau. Jumlah tersebut termasuk sekitar 600.000 orang yang meninggal akibat dari asap tangan kedua (secondhand smoking) (World Health Organization, 2015, hal. 1).

Berbagai upaya penanganan untuk mengurangi jumlah insiden telah dilakukan, salah satunya yaitu Framework Convention on Tobacco Control (FCTC). World Health Assembly pada tahun 2003 sepakat untuk mengadopsi Framework Convention on Tobacco Control (FCTC) dari WHO. Tujuan utama dari FCTC adalah untuk melindungi generasi masa kini dan mendatang dari konsekuensi- konsekuensi dari konsumsi dan paparan tembakau yang menghancurkan kesehatan, sosial, lingkungan dan ekonomi (World Health Organization, 2015, hal. $1)$.

Indonesia telah memiliki peraturan perundang-undangan yang mengatur mengenai kawasan bebas asap rokok. Dalam Pasal 115 Undang-Undang Nomor 36 Tahun 2009 dan Pasal 49 Peraturan Pemerintah Nomor 109 Tahun 2012 menyebutkan bahwa Pemerintah dan Pemerintah Daerah wajib mewujudkan Kawasan Bebas Rokok. Secara lokal, pemerintah Kota Semarang juga telah mengeluarkan Peraturan Daerah Kota Semarang Nomor 13 Tahun 2006 tentang Kawasan Tanpa Rokok (KTR) Kota Semarang di berbagai tempat. 
Salah satu tempat yang dicantumkan dalam peraturanperaturan tersebut adalah tempat belajar mengajar. Hal ini telah diterapkan oleh Fakultas Psikologi Universitas

Katolik

Soegijapranata Semarang dengan memberikan larangan merokok di Gedung Antonius yang merupakan gedung tempat proses belajar mengajar dari program studi psikologi. Larangan merokok tersebut diatur dalam Peraturan Fakultas Psikologi Universitas Katolik Soegijapranata Nomor 503/H.4/FP/I/2014 mengenai Kawasan Bebas Asap Rokok pada seluruh gedung dan ruangan yang digunakan oleh Fakultas Psikologi. Peraturan ini telah ditetapkan sejak 2 Januari 2014.

Sikap mahasiswa terhadap aturan tersebut berbeda-beda. Terdapat berbagai hal yang memengaruhi sikap mahasiswa. Hal ini seperti yang diungkapkan dalam TRA (Theory of Reasoned Actions) bahwa sikap dipengaruhi oleh keyakinan individu terhadap hasil yang diperoleh atau yang disebut behavioral belief (Ajzen \& Fishbein, 2005, hal. 194).

Akan tetapi, hal tersebut juga dipengaruhi oleh faktorfaktor lain yang membentuk sikap mahasiswa tersebut. Azwar (Sikap Manusia: Teori dan Pengukurannya, 2015, hal. 32-38) dalam bukunya mengungkapkan berbagai faktor yang memengaruhi sikap seperti pengaruh orang lain yang dianggap penting, kebudayaan, dan media massa.

Beberapa penelitian yang telah dilakukan menemukan beberapa faktor lain yang memengaruhi sikap khususnya sikap terhadap larangan merokok. Penelitian-penelitian tersebut 
menemukan bahwa sikap terhadap larangan merokok dipengaruhi oleh status merokok, niat untuk berhenti merokok, dan juga jenis kelamin (Rigotti, Regan, Moran, \& Wechsler, 2003, hal. 252; Chaaya, et al., 2013, hal. 6).

Oleh karena itu, penelitian ini dilakukan untuk memberikan gambaran mengenai faktor-faktor yang memengaruhi sikap mahasiswa Fakultas Psikologi Universitas Katolik

Soegijapranata

Semarang terhadap larangan merokok di Gedung Antonius, Fakultas Psikologi Universitas Katolik Soegijapranata

Semarang.

\section{Bagan 1}

Kerangka Berpikir

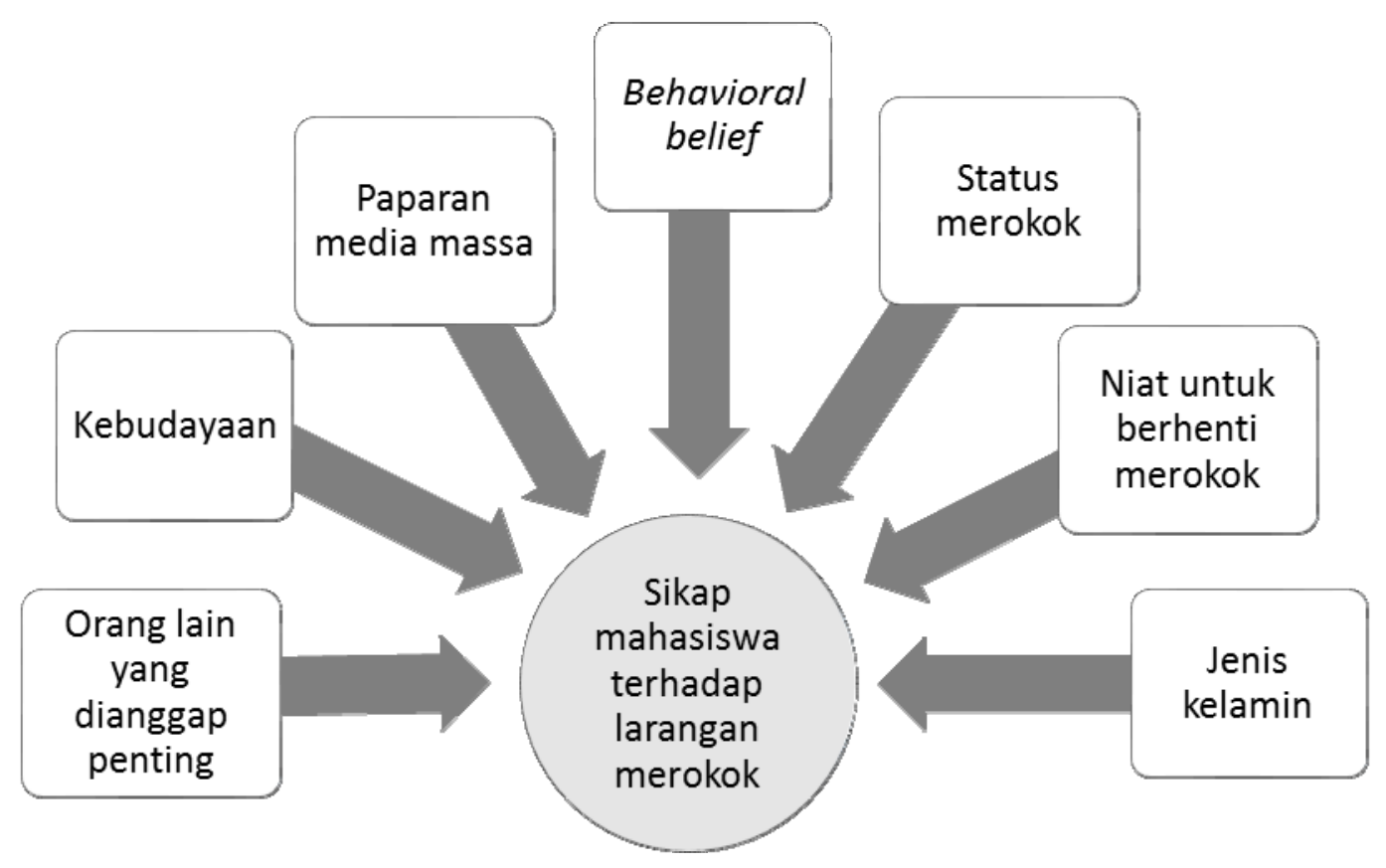




\section{HIPOTESIS}

- Ada hubungan antara orang lain yang dianggap penting dan sikap mahasiswa terhadap larangan merokok.

- Ada perbedaan sikap mahasiswa terhadap larangan merokok berdasarkan kebudayaan.

- Ada perbedaan sikap mahasiswa terhadap larangan merokok berdasarkan frekuensi paparan media masa.

- Ada hubungan antara behavioral belief dan sikap mahasiswa terhadap larangan merokok.

- Ada perbedaan sikap mahasiswa terhadap larangan merokok berdasarkan status merokok.

- Ada perbedaan sikap mahasiswa terhadap larangan merokok berdasarkan niat untuk berhenti merokok.

- Ada perbedaan sikap mahasiswa terhadap larangan merokok berdasarkan jenis kelamin.

\section{METODE PENELITIAN}

Jenis penelitian yang dilakukan oleh peneliti apabila dilihat berdasarkan pendekatan analisisnya merupakan jenis penelitian dengan pendekatan kuantitatif. Pendekatan kuantitatif merupakan pendekatan yang analisisnya didasarkan oleh data numerik yang diolah menggunakan metode statistika. Sedangkan berdasarkan kedalaman analisis dan karakteristik masalah, penelitian ini tergolong sebagai penelitian deskriptif.

\section{Populasi dan Sampel \\ Populasi dari penelitian ini adalah mahasiswa Fakultas}


Psikologi Universitas Katolik mengungkap mengenai jenis Soegijapranata Semarang. kelamin, kebudayaan, paparan Populasi penelitian terdiri dari media massa, status merokok, dan berbagai tahun angkatan mulai niat untuk berhenti merokok. dari tahun angkatan 2012 hingga Selain itu, penelitian ini juga 2015. Dari populasi tersebut, menggunakan tiga buah skala sampel diambil menggunakan dengan empat pilihan jawaban. teknik quota sampling sebanyak Skala ini akan mengungkap 100 mahasiswa.

\section{Metode Pengumpulan Data}

Penelitian ini dianggap penting, behavioral menggunakan kuesioner yang belief. berisikan pertanyaan yang mengenai sikap terhadap larangan merokok, orang lain yang Metode Analisis Data

Tabel 1

Metode Analisis Statistik

\begin{tabular}{|c|l|c|}
\hline Variabel Tergantung & \multicolumn{1}{|c|}{ Variabel Bebas } & \multicolumn{1}{c|}{ Metode } \\
\hline \multirow{5}{*}{$\begin{array}{c}\text { Sikap terhadap larangan } \\
\text { merokok pada } \\
\text { mahasiswa }\end{array}$} & $\begin{array}{l}\text { Orang lain yang dianggap } \\
\text { penting }\end{array}$ & $\begin{array}{c}\text { Spearman's rank } \\
\text { correlation }\end{array}$ \\
\cline { 2 - 3 } \begin{tabular}{c} 
Kebudayaan \\
\cline { 2 - 3 }
\end{tabular} & Paparan media massa & Kruskal-Wallis \\
\cline { 2 - 3 } & Behavioral belief & $\begin{array}{c}\text { Spearman'-Wallis } \\
\text { correlation }\end{array}$ \\
\cline { 2 - 3 } & $\begin{array}{l}\text { Status merokok: } \\
-\quad \text { Status perokok aktif }\end{array}$ & $\begin{array}{c}\text { Mann-Whitney } \\
\text { Kruskal-Wallis }\end{array}$ \\
\cline { 2 - 3 } & - Frekuensi merokok & Kruskal-Wallis \\
\cline { 2 - 3 } & Niat untuk berhenti merokok & Mann-Whitney \\
\cline { 2 - 3 } & Jenis kelamin & \\
\hline
\end{tabular}




\section{HASIL DAN PEMBAHASAN}

Skor skala digolongkan

menjadi empat yaitu sangat setuju (skor 68), setuju (skor 51-67), tidak setuju (skor 34-50), dan sangat tidak setuju (skor 17-33). Berikut ini adalah data Skala Sikap Terhadap Larangan Merokok:

Tabel 2

Hasil Skala Sikap Terhadap Larangan Merokok

\begin{tabular}{|l|c|c|c|}
\hline \multicolumn{1}{|c|}{ Sikap } & Nilai & Jumlah Subjek & Persentase \\
\hline Sangat Setuju & 68 & 16 & $16 \%$ \\
\hline Setuju & $51-67$ & 64 & $64 \%$ \\
\hline Tidak Setuju & $34-50$ & 14 & $14 \%$ \\
\hline Sangat Tidak Setuju & $17-33$ & 6 & $6 \%$ \\
\hline \multicolumn{2}{|c|}{ Total } & $\mathbf{1 0 0}$ & $\mathbf{1 0 0 \%}$ \\
\hline
\end{tabular}

Orang lain yang dianggap penting diungkap menggunakan Skala Orang lain yang berisi enam buah item. Hasil skala digolongkan menjadi empat golongan berdasarkan total skor skala sebagai berikut:

Tabel 3

Hasil Skala Orang lain

\begin{tabular}{|l|c|c|c|}
\hline \multicolumn{1}{|c|}{ Sikap } & Nilai & $\begin{array}{c}\text { Jumlah } \\
\text { Subjek }\end{array}$ & Persentase \\
\hline Sangat Dipengaruhi & 24 & 2 & $2 \%$ \\
\hline Dipengaruhi & $18-23$ & 13 & $13 \%$ \\
\hline Tidak Dipengaruhi & $12-17$ & 46 & $46 \%$ \\
\hline $\begin{array}{l}\text { Sangat Tidak } \\
\text { Dipengaruhi }\end{array}$ & $6-11$ & 39 & $39 \%$ \\
\hline \multicolumn{2}{|c|}{ Total } & $\mathbf{1 0 0}$ & $\mathbf{1 0 0 \%}$ \\
\hline
\end{tabular}


Kebudayaan subjek etnis yang ada dalam sampel yang penelitian pada awalnya dibagi dapat digunakan dalam analisis menjadi enam kelompok etnis data adalah Jawa, Tionghoa, dan yaitu Batak, Jawa, Papua, campuran. Hal ini dikarenakan Tionghoa, campuran dan lainnya, jumlah sampel etnis Batak, Papua, akan tetapi data yang diperoleh dan lainnya terlalu sedikit atau peneliti menunjukkan kelompok tidak ada sama sekali.

Tabel 4

\section{Etnis Sampel Penelitian}

\begin{tabular}{|c|c|c|c|}
\hline Etnis & Jumlah & Persentase & Rata-rata \\
\hline Batak & 1 & $1 \%$ & - \\
\hline Jawa & 52 & $52 \%$ & 58,87 \\
\hline Papua & 0 & $0 \%$ & - \\
\hline Tionghoa & 30 & $30 \%$ & 53,73 \\
\hline Campuran & 16 & $16 \%$ & 59,63 \\
\hline Lainnya & 1 & $1 \%$ & - \\
\hline Total & $\mathbf{1 0 0}$ & $\mathbf{1 0 0} \%$ & $\mathbf{5 7 , 4 7}$ \\
\hline
\end{tabular}

Paparan media massa tidak mendukung perilaku digolongkan menjadi dua yaitu merokok (peringatan bahaya media yang mendukung perilaku rokok dan iklan layanan merokok (iklan rokok) dan yang masyarakat).

Tabel 25

Paparan Media Massa dalam Satu Minggu Terakhir

\begin{tabular}{|c|c|c|c|}
\hline Frekuensi & Iklan Rokok & $\begin{array}{c}\text { Peringatan } \\
\text { Bahaya Rokok }\end{array}$ & $\begin{array}{c}\text { Layanan } \\
\text { Masyarakat }\end{array}$ \\
\hline$<3$ & $25(25 \%)$ & $28(28 \%)$ & $43(43 \%)$ \\
\hline $3-6$ & $36(36 \%)$ & $33(33 \%)$ & $31(31 \%)$ \\
\hline $7-10$ & $12(12 \%)$ & $18(18 \%)$ & $13(13 \%)$ \\
\hline$>10$ & $27(27 \%)$ & $21(21 \%)$ & $13(13 \%)$ \\
\hline Total & $\mathbf{1 0 0 ( 1 0 0 \% )}$ & $\mathbf{1 0 0 ( 1 0 0 \% )}$ & $\mathbf{1 0 0 ( 1 0 0 \% )}$ \\
\hline
\end{tabular}


Behavioral belief diukur dengan menggunakan skala yang berisi enam item. Behavioral belief akan digolongkan menjadi empat golongan yaitu seperti pada Tabel 6.

\section{Tabel 6}

Hasil Skala Behavioral Belief

\begin{tabular}{|l|c|c|c|}
\hline \multicolumn{1}{|c|}{ Sikap } & Nilai & Jumlah Subjek & Persentase \\
\hline Sangat Positif & 24 & 2 & $2 \%$ \\
\hline Positif & $18-23$ & 13 & $13 \%$ \\
\hline Negatif & $12-17$ & 46 & $46 \%$ \\
\hline Sangat Negatif & $6-11$ & 39 & $39 \%$ \\
\hline \multicolumn{2}{|c|}{ Total dari } & $\mathbf{1 0 0}$ & $\mathbf{1 0 0 \%}$ \\
\hline \multicolumn{2}{|c|}{ Nata yang diperoleh duk berhenti }
\end{tabular}

kuesioner menunjukkan bahwa jumlah sampel yang merupakan perokok aktif adalah $46(46 \%)$ dan yang bukan merupakan perokok aktif adalah 54 (54\%).

Selain status perokok aktif dan bukan perokok aktif, variabel status merokok juga diukur menggunakan frekuensi merokok. Frekuensi merokok sampel yang diperoleh adalah tidak pernah merokok 54 (54\%) mahasiswa, kadang-kadang 18 (18\%), dan setiap hari $28(28 \%)$. merokok pada mahasiswa hanya diambil dari mahasiswa yang merupakan perokok aktif. Hasil dari sampel data yang diperoleh dicantumkan dalam tabel berikut ini: 
Tabel 7

Sampel Niat untuk Berhenti Merokok

\begin{tabular}{|l|c|c|}
\hline \multicolumn{1}{|c|}{ Niat Berhenti } & Jumlah Subjek & Persentase \\
\hline Tidak Sama Sekali & 9 & $9 \%$ \\
\hline Mungkin & 22 & $22 \%$ \\
\hline Sangat Mungkin & 6 & $6 \%$ \\
\hline Sangat Berniat & 9 & $9 \%$ \\
\hline Total & $\mathbf{4 6}$ & $\mathbf{4 6 \%}$ \\
\hline
\end{tabular}

Penelitian ini membedakan

sikap berdasarkan jenis kelamin

mahasiswa. Data jenis kelamin mahasiswa yang diperoleh adalah

sebagai

berikut:

Tabel 8

Sikap Terhadap Larangan Merokok Berdasarkan Jenis Kelamin

\begin{tabular}{|c|c|c|}
\hline Jenis Kelamin & Jumlah Subjek & Persentase \\
\hline Laki-laki & 51 & $51 \%$ \\
\hline Perempuan & 49 & $49 \%$ \\
\hline
\end{tabular}

\section{Pembahasan}

Data penelitian yang

diperoleh menunjukkan bahwa kawasan bebas asap rokok di

Gedung Antonius disikapi secara positif oleh sebagian besar mahasiswa. Hasil Skala Sikap Mahasiswa Terhadap Larangan merokok yang diperoleh menunjukkan $80 \% \quad(\mathrm{n}=100)$ mahasiswa bersikap positif terhadap kawasan bebas asap rokok di Gedung Antonius. Jumlah mahasiswa yang bersikap negatif sebesar $20 \%$ dari total subjek dan mahasiswa yang memiliki sikap sangat negatif hanya $6 \%$.

Sikap terhadap larangan merokok pada mahasiswa 
dipengaruhi oleh berbagai faktor yang dianalisis menggunakan metode statistik. Hasil analisis data menunjukkan bahwa faktorfaktor yang memengaruhi sikap mahasiswa dalam penelitian ini adalah orang lain yang dianggap penting, behavioral belief, status merokok, niat untuk berhenti merokok dan jenis kelamin. Sedangkan, faktor kebudayaan dan paparan media massa tidak menunjukkan adanya pengaruh pada sikap mahasiswa terhadap larangan merokok.

Tabel 9

Hasil Analisis Faktor-Faktor yang Memengaruhi Sikap Terhadap Larangan Merokok

\begin{tabular}{|l|c|c|c|}
\hline \multicolumn{1}{|c|}{ Faktor } & $\begin{array}{c}\text { Jumlah } \\
\text { Subjek }\end{array}$ & Hasil & Signifikansi \\
\hline $\begin{array}{l}\text { Orang lain yang dianggap } \\
\text { penting }\end{array}$ & 100 & $\rho(98)=-0,471$ & $(\mathrm{p}<0,01)$ \\
\hline Kebudayaan & 98 & $\chi^{2}(3)=3,578$ & $(\mathrm{p}>0,05)$ \\
\hline $\begin{array}{l}\text { Paparan Media Massa } \\
\text { Iklan Rokok }\end{array}$ & 100 & $\chi^{2}(3)=2,114$ & $(\mathrm{p}>0,05)$ \\
Peringatan Bahaya Rokok & 100 & $\chi^{2}(3)=5,990$ & $(\mathrm{p}>0,05)$ \\
Iklan Layanan Masyarakat & 100 & $\chi^{2}(3)=5,722$ & $(\mathrm{p}>0,05)$ \\
\hline Behavioral Belief & 100 & $\rho(98)=0,863$ & $(\mathrm{p}<0,01)$ \\
\hline Status Merokok & 100 & $\mathrm{U}=418,00$ & $(\mathrm{p}<0,01)$ \\
Status Perokok Aktif & 100 & $\chi^{2}(2)=43,073$ & $(\mathrm{p}<0,01)$ \\
Frekuensi Merokok & 46 & $\chi^{2}(3)=14,677$ & $(\mathrm{p}<0,01)$ \\
\hline Niat untuk Berhenti Merokok & 100 & $\mathrm{U}=634,00$ & $(\mathrm{p}<0,01)$ \\
\hline Jenis Kelamin & \multicolumn{3}{|c}{} \\
\hline
\end{tabular}

Terdapat hubungan yang negatif yang sangat signifikan antara orang lain yang dianggap penting dengan sikap mahasiswa terhadap larangan merokok di Gedung Antonius. Hal ini berbeda dengan teori yang telah diungkapkan oleh Azwar (Sikap 
Manusia: $\quad$ Teori dan Pengukurannya, 2015, hal. 32) yang menyatakan bahwa individu memilki kecenderungan untuk memiliki sikap yang searah dengan orang yang dianggapnya penting. Akan tetapi, pada penelitian ini juga ditemukan bahwa terdapat hubungan yang lebih kuat antara sikap terhadap larangan merokok dan behavioral belief. Mahasiswa pada penelitian ini lebih yakin terhadap hasil yang akan diterima sehingga tidak mudah terpengaruh oleh orang lain.

Penelitian ini menemukan bahwa behavioral belief yang dimiliki oleh mahasiswa mengenai larangan merokok memiliki hubungan positif yang sangat signifikan $(\rho(98)=0,863$, $\mathrm{p}<0,01)$. Hal ini sejalan dengan penelitian yang telah dilakukan mengenai perilaku bebas rokok pada siswa di Kanada. Penelitian tersebut menemukan bahwa behavioral belief memiliki asosiasi signifikan yang sedang hingga tinggi terhadap sikap (Murnaghan, et al., 2009, hal. 477).

Akan tetapi, hasil penelitian lain menunjukkan hasil yang bertentangan. Utami (2007, hal. 155) dalam penelitiannya yang dilakukan kepada pasangan suami istri menemukan bahwa menunjukkan sikap lebih dipengaruhi oleh faktor eksternal seseorang. Hal ini menunjukkan bahwa terdapat perbedaan faktor yang memengaruhi sikap seseorang berdasarkan usia atau status marital.

Mahasiswa yang tidak merokok (mean rank $=65,76$ ) memiliki sikap yang lebih positif dibandingkan dengan yang merokok (mean rank $=32,59)$. 
Hasil penelitian ini sejalan dengan penelitian-penelitian sebelumnya yang telah dilakukan (Rigotti, Regan, Moran, \& Wechsler, 2003, hal. 252; Chaaya, et al., 2013, hal. 6). Selain itu, sebuah penelitian mengenai sikap dan perilaku mahasiswa terhadap larangan merokok yang diadakan di sebuah universitas negeri di Amerika Serikat juga mendukung temuan ini. Penelitian tersebut juga menggunakan status merokok aktif dan frekuensi merokok mahasiswa sebagai variabel penelitian. (Butler, Rayens, Hahn, Adkins, \& Staten, 2011, hal. 261). Penelitian yang dilakukan di Australia Barat menunjukkan hal yang serupa (Rosenberg, Pettigrew, Wood, Ferguson, \& Houghton, 2012, hal. 3). Selain itu, sebuah penelitian lain yang diadakan di Amerika Serikat membandingkan hasil survei nasional dari tiga periode juga menunjukkan hal yang serupa (Gilpin, Lee, \& Pierce, 2004, hal. 42).

Frekuensi merokok mahasiswa menggambarkan bahwa mahasiswa yang merokok setiap hari $($ mean rank $=21,57)$ memiliki sikap lebih negatif dibandingkan mahasiswa yang kadang-kadang merokok (mean rank $=49,72)$ dan yang tidak pernah merokok (mean rank = $65,76)$.

Faktor lain yang berpengaruh pada sikap terhadap larangan merokok dari ini adalah niat untuk berhenti merokok. Perokok aktif yang memiliki niat yang lebih tinggi untuk berhenti merokok dalam waktu 30 hari ke depan memiliki sikap yang lebih positif dibandingkan dengan yang memiliki niat lebih rendah. Hasil dari penelitian ini mendukung apa 
yang diungkapkan dalam penelitian Doucet, Velicer, \& Laforge (2007, hal. 149) bahwa perokok yang tidak memiliki niat untuk berhenti dalam waktu dekat memiliki sikap yang kurang mendukung terhadap perturan pengendalian penggunaan tembakau dibandingkan perokok yang memiliki niat untuk berhenti. Jenis kelamin merupakan salah satu faktor demografis yang memengaruhi sikap mahasiswa terhadap larangan merokok secara signifikan $(U=634,00, p<0,01)$. Hasil penelitian ini menunjukkan bahwa perempuan (mean rank = 63,06) memiliki sikap yang lebih positif dibandingkan dengan lakilaki (mean rank = 38,43). Berbagai penelitian yang telah dilakukan juga menemukan hal yang sama dengan hasil penelitian ini (Doucet, Velicer, \& Laforge, 2007, hal. 153; Gilpin, Lee, \&
Pierce, 2004, hal. 42; Rashid, Manan, Yahya, \& Ibrahim, 2014, hal. 4).

Hasil analisis data variabel jenis kelamin pada penelitian ini mungkin disebabkan oleh jumlah sampel berjenis kelamin perempuan sebagian besar bukan perokok aktif. Jumlah sampel perempuan yang bukan merupakan perokok aktif sebanyak 38 (38\%), sedangkan yang merupakan perokok aktif sebanyak 11 (11\%). Sebaliknya, jumlah sampel laki-laki yang bukan perokok aktif sebanyak 16 $(16 \%)$ dan perokok aktif 35 $(35 \%)$.

Faktor kebudayaan menunjukkan tidak ada perbedaan sikap antara etnis Jawa, Tionghoa, dan campuran $\left(\chi^{2}(2)=3,578\right.$, $\mathrm{p}>0,05)$. Hal ini juga terjadi pada penelitian serupa yang dilakukan di Amerika. Penelitian tersebut 
membahas tentang pengaruh perbedaan demografi terhadap peraturan merokok dan salah satu variabel penelitian tersebut adalah etnis. Hasil penelitian tersebut menunjukkan bahwa tidak ada perbedaan signifikan antara etnis yang terdapat pada sampel penelitian (Doucet, Velicer, \& Laforge, 2007, hal. 153).

Kebudayaan yang dalam hal ini adalah etnis, tidak signifikan memengaruhi dimungkinkan karena sikap terhadap larangan merokok bukanlah suatu hal yang khas dari etnis tertentu pada sampel penelitian. Peraturan kawasan bebas asap rokok telah dicantumkan dalam perundangundangan sehingga merupakan hal yang umum, bukan sesuatu hal khusus pada suatu etnis.

Faktor lain yang juga tidak menunjukkan pengaruh yang signifikan terhadap sikap mahasiswa adalah paparan media massa. Media massa pada penelitian ini dibagi menjadi tiga macam yaitu iklan rokok, peringatan bahaya merokok, dan iklan layanan masyarakat. Data yang diperoleh menunjukkan bahwa iklan rokok memiliki nilai paling banyak dijumpai (>10 kali) oleh responden yaitu sebanyak 28 (28\%) responden, sedangkan iklan layanan masyarakat nilai paling jarang dijumpai (<3 kali) oleh responden yaitu sebanyak 43 (43\%) responden.

Iklan rokok tidak memengaruhi sikap mahasiswa secara signifikan meskipun merupakan media yang paling sering dijumpai. Media massa tidaklah memiliki pengaruh yang signifikan dikarenakan media massa tidak memiliki hubungan yang dekat, tidak bernilai, dan 
tidak melibatkan emosi seseorang (Simons-Morton \& Farhat, 2010, hal. 195). Hal tersebut juga berlaku pada aspek-aspek media massa lainnya pada penelitian ini.

Peringatan mengenai bahaya rokok tidaklah memberikan informasi yang tidak diketahui oleh perokok sehingga hal tersebut diabaikan. Sebuah penelitian yang dilakukan di kota Surabaya menunjukkan bahwa pesan kesehatan pada kemasan rokok belum berdampak pada pengetahuan dan pencegahan perilaku merokok (Widati, 2013, hal. 110).

Selain itu, iklan layanan masyarakat mengenai rokok juga tidak cukup efektif. Sebuah penelitian menunjukkan bahwa pesan yang disampaikan melalui iklan layanan masyarakat tidaklah cukup efektif (netral) dalam mempromosikan perilaku anti rokok (Hong, Soh, Khan, Abdullah, \& Teh, 2013, hal. 58).

\section{KESIMPULAN}

Berdasarkan penelitian ini maka dapat disimpulkan bahwa faktor-faktor yang sangat signifikan $(\mathrm{p}<0,01)$ memengaruhi sikap terhadap larangan merokok pada mahasiswa adalah sebagai berikut:

1. Behavioral belief

2. Jenis kelamin

3. Orang lain yang dianggap penting

4. Status merokok

5. Niat untuk berhenti merokok Sedangkan, faktor kebudayaan dan paparan media masa tidak berpengaruh secara signifikan $(p>0,05)$ pada sikap mahasiswa terhadap larangan merokok.

\section{SARAN}

Bagi Fakultas Psikologi Universitas Katolik Soegijapranata Semarang 
Fakultas

Psikologi

Universitas

Katolik

Soegijapranata

dapat

menggunakan faktor-faktor yang

memengaruhi secara signifikan

sikap mahasiswa terhadap

larangan merokok seperti:

a. Behavioral belief

Fakultas Psikologi Universitas

Katolik Soegijapranata dapat

lebih sering memberikan sosialisasi di berbagai kegiatan tidak hanya dalam PTMB melainkan juga pada acara lain seperti hari tembakau sedunia. Sosialisasi tersebut dapat memberikan informasi mengenai manfaat larangan merokok serta sanksi yang terdapat pada larangan merokok di Gedung Antonius. Sehingga akan meningkatkan behavioral belief terhadap larangan merokok.

b. Jenis kelamin
Fakultas Psikologi Universitas Katolik Soegijapranata sebaiknya lebih meningkatkan sosialisasi khususnya bagi laki-laki. Hal ini dapat dilakukan salah satunya dengan memasang peringatan atau poster mengenai larangan merokok di toilet laki-laki.

c. Orang lain yang dianggap penting

Orang lain yang dianggap penting dapat berupa dosen maupun karyawan di Fakultas Psikologi Universitas Katolik Soegijapranata. Sehingga, para dosen maupun karyawan harus mendukung peraturan mengenai larangan merokok dengan tidak melanggar dan juga menegur orang yang melanggar larangan ini.

d. Status merokok

Fakultas Psikologi Universitas Katolik Soegijapranata 


$\begin{array}{ll}\text { sebaiknya memfasilitasi } & \text { mematuhi larangan merokok di } \\ \text { mahasiswa yang ingin } & \text { kampus bagi kesehatan warga } \\ \text { berhenti merokok. Fakultas } & \text { Fakultas Psikologi. } \\ \text { dapat membuka kesempatan } & \text { Bagi Peneliti Selanjutnya }\end{array}$

konsultasi bagi mahasiswa yang ingin berhenti merokok sehingga dapat membantu dalam mengurangi jumlah perokok aktif.

e. Niat untuk berhenti merokok

Fakultas Psikologi dapat bekerjasama dengan

Universitas untuk melarang penjualan rokok di area kampus. Hal ini bertujuan untuk membantu mahasiswa yang ingin berhenti merokok sehingga tidak dengan mudah memperoleh rokok.

\section{Bagi Mahasiswa Fakultas}

Psikologi Universitas Katolik Soegijapranata

$$
\begin{aligned}
& \text { Mahasiswa seharusnya } \\
& \text { menyadari akan pentingnya } \\
& \text { penerapan larangan merokok dan }
\end{aligned}
$$

a. Peneliti yang hendak melakukan penelitian serupa sebaiknya menggunakan jumlah sampel yang lebih banyak. Selain itu peneliti juga dapat menggunakan sampel dengan etnis yang lebih beragam sehingga hasil penelitian dapat lebih digeneralisir.

b. Penelitian selanjutnya dapat menggunakan sampel yang tidak hanya berasal dari mahasiswa Fakultas Psikologi namun juga mahasiswa fakultas lain maupun semua orang yang menggunakan atau datang ke Gedung Antonius.

c. Peneliti selanjutnya dapat melakukan penelitian lebih 
lanjut mengenai media massa yang paling efektif dalam meningkatkan sikap mahasiswa terhadap larangan merokok.

d. Penelitian selanjutnya dapat menggunakan metode penelitian kualitatif sehingga dapat mengetahui dinamika psikologis yang memengaruhi sikap mahasiswa terhadap larangan merokok.

\section{DAFTAR PUSTAKA}

Ajzen, I., \& Fishbein, M. (2005). The Influence of Attitudes on Behavior. Dalam D. Albarracin, B. T. Johnson, \& M. P. Zanna (Penyunt.), The Handbook of Attitudes (hal. 173-221). Mahwah: Lawrence Erlbaum Associates.

Butler, K. M., Rayens, M. K., Hahn, E. J., Adkins, S. M., \& Staten, R. R. (2011). Smoke-Free Policy and Alcohol Use Among Undergraduate College Students. Public Health Nursing, 29(3), 256-265. doi:10.1111/j.15251446.2011.01000.x
Chaaya, M., Alameddine, M., Nakkash, R., Afifi, R. A., Khalil, J., \& \& Nahhas, G. (2013). Students' Attitude and Smoking Behaviour Following the Implementation of A University Smoke-free Policy: A Cross-sectional Study. BMJ Open, 3, 1-8. doi:10.1136/bmjopen2012-002100

Doucet, J. M., Velicer, W. F., \& Laforge, R. G. (2007). Demographic Differences in Support for Smoking Policy Interventions.

Addictive Behaviors, 32, 148-157.

doi:10.1016/j.addbeh.2006. 04.003

Finegan, B. A., \& Finegan, G. J. (2011). From Discarded Leaf to Global Scourage The Extraordinary History of the Ascent of Tobacco and its Many Modes of Consumption. Dalam D. Benhard (Penyunt.), Cigarette Smoke Toxicity: Linking Individual Chemical to Human Diseases (hal. 2). Weinheim: Wiley-VCH.

Gilpin, E. A., Lee, L., \& Pierce, J. P. (2004). Changes in population attitudes about where smoking should not be allowed: California versus the rest of the USA. Tob Control, 13, 38-44. doi:10.1136/tc.2003.00473 9 
Hong, Y. H., Soh, C. H., Khan, N., Abdullah, M. M., \& Teh, B. H. (2013). Effectiveness of AntiSmoking Advertising: The Roles of Message and Media. International Journal of Business and Management, 8(19), 5562.

doi:10.5539/ijbm.v8n19p5 5

Murnaghan, D. A., Blanchard, C., Rodgers, W., Rosa, J. L., Macquarrie, C., Maclellan, D., \& Gray, B. (2009, Oktober). The influence of student-level normative, control and behavioral beliefs on staying smokefree: An application of Ajzen's theory of planned behavior. Addiction Research and Theory, 17(5), 469-480. doi:10.1080/160663508020 11649

Rashid, A., Manan, A. A., Yahya, N., \& Ibrahim, L. (2014, Oktober). The Support for Smoke Free Policy and How It Is Influenced by Tolerance to Smoking Experience of a Developing Country. PLOS ONE, 9(10), 1-7. doi:10.1371/journal.pone.0 109429

Rigotti, N. A., Regan, S., Moran, S. E., \& Wechsler, H. (2003). Students' Opinion of Tobacco Control Policies Recommended for
US Colleges: A National Survey. Tobbaco Control, 12, 251-256. doi:10.1136/tc.12.3.251

Rosenberg, M., Pettigrew, S., Wood, L., Ferguson, R., \& Houghton, S. (2012). Public Support for Tobacco Control Policy Extensions in Western Australia: a Cross-sectional Study. BMJ Open, 2(2), 1-8. doi:10.1136/bmjopen2011-000784

Simons-Morton, B., \& Farhat, T. (2010). Recent Findings on Peer Group Influences on Adolescent Substance Use. The Journal of Primary Prevention, 31(4), 191208. doi:10.1007/s10935010-0220-x

Utami, M. S. (2007). Pregnancy and Giving Birth in Couples From CentralJava: Contributions From Psychology to Safe Motherhood. Nijmegen: Radboud University.

Widati, S. (2013). Efektivitas Pesan Bahaya Rokok Pada Bungkus Rokok Terhadap Perilaku Merokok Masyarakat Miskin. Jurnal Promkes, 1(2), 105-110.

World Health Organization. (2015). WHO Global Report on Trends in Prevalence of Tobacco Smoking 2015. Geneva: World Health Organization. Dipetik 
August 22, 2015, dari http://www.who.int

Yahya, A. F. (2010). Menaklukkan Pembunuh

No. 1: Mencegah dan Mengatasi Penyakit Jantung Koronener Secara Cepat dan Tepat. Bandung: Qanita, PT Mizan Digital Publishing. 